Chorobotwórczość Aggregatibacter actinomycetemcomitans w świetle ostatnich badań

\title{
Pathogenicity of Aggregatibacter actinomycetemcomitans in the light of recent research
}

Jan Kowalski

Zakład Chorób Błony Śluzowej i Przyzębia, Warszawki Uniwersytet Medyczny, Warszawa

Aggregatibacter actinomycetemcomitans jest bakterią powszechnie wiązaną z agresywnym zapaleniem przyzębia. W pracy omówiono serotypy patogenu i potencjalne mechanizmy odpowiedzialne za przyspieszone niszczenie tkanek przyzębia.

Słowa kluczowe: Aggregatibacter actinomycetemcomitans, czynniki wirulencji, agresywne zapalenie przyzębia

\begin{abstract}
Aggregatibacter actinomycetemcomitans is commonly tied with aggressive periodontitis. Paper describes pathogen's serotypes and potential mechanisms responsible for the accelerated periodontal tissue destruction.
\end{abstract}

Key words: Aggregatibacter actinomycetemcomitans, virulence factors, aggressive periodontitis

\section{WSTĘP}

Aggregatibacter actinomycetemcomitans jest patogenem związanym z agresywnym zapaleniem przyzębia. Ta jednostka chorobowa została ujęta w obowiązującej do dzisiaj klasyfikacji AAP z 1999 roku. Jakkolwiek niemal pewnym jest, że w momencie publikacji tego artykułu klasyfikacja już uległa zmianie na nową (powstałą we współpracy EFP i AAP, ustaloną w Chicago w listopadzie 2017 roku, a nowa klasyfikacja prawdopodobnie nie będzie uwzględniała rozpoznania ,,agresywne zapalenie przyzębia”), to należy pamiętać, że zmiana nomenklatury nie spowoduje zmiany w patogenności bakterii. A.actinomycetemcomitans cały czas będzie kojarzony z zapaleniem przyzębia, nasilo- 
nym przy siekaczach przyśrodkowych i pierwszych zębach trzonowych. Podobnie jak we wcześniejszych klasyfikacjach, występowanie tego drobnoustroju korelowało z młodzieńczym zapaleniem przyzębia, w mniejszym stopniu z gwałtownie postępującym zapaleniem przyzębia czy też - jeszcze wcześniej - z periodontitis gravis et complicata lub desmodontozą. Odpowiedzialny za to jest bowiem szczególny fenotyp tej bakterii.

Klasyfikacja tej bakterii na przestrzeni ostatnich stu lat ulegała zmianie trzykrotnie. W 1929 roku została przemianowana na Actinobacillus actinomycetemcomitans, w latach 80-tych przekwalifikowana na Haemophilus actinomycetemcomitans (36). W roku 2006 taksonomia uległa kolejnej zmianie i ostatecznie ustalono nazwę na używaną obecnie (34). Jest to Gram-ujemna, nieruchoma pałeczka względnie beztlenowa, jak wskazuje nazwa, towarzysząca promieniowcom, należąca do rodziny Pasteurellaceae. Dyskusyjny jest podział typów tej bakterii. Pierwotnie bakterię typowano zależnie od potencjału leukotoksycznego na bakterie o niskiej lub wysokiej zdolności eliminacji leukocytów (odpowiednio genotypy non-JP2 i JP2) (44). Zespół prof. Slotsa ustalił inny podział - na podstawie budowy polisacharydów błonowych (A.actinomycetemcomitans wykryto u 85 pacjentów z ponad 400 osobowej grupy badanej) wydzielono sześć podstawowych serotypów tego patogenu, z czego najczęściej w jamie ustnej występują trzy, oznaczone literami a, b oraz c (48). Wg badania Perry'ego i wsp. (35) serotypy a i b w niemal równej proporcji są oznaczane u osób zdrowych i z przewlekłym zapaleniem przyzębia (wówczas określanym jako zapalenie przyzębia dorosłych), serotyp b występuje jednakże niemal dwukrotnie częściej w agresywnym zapaleniu przyzębia (wówczas młodzieńczym zapaleniu przyzębia), serotyp c pojawia się rzadziej, w równych proporcjach, i odpowiada przede wszystkim za infekcje poza jamą ustną. Najczęstszymi takimi zakażeniami są ropnie mózgu oraz zapalenie kości i zapalenie wsierdzia (37), natomiast według Zambona i wsp. (4) pałeczki serotypu c znajdowane są u osób zdrowych. Pałeczki A.actinomycetemcomitans należące do serotypów d i e występują na tyle rzadko, że ich właściwości nie są scharakteryzowane (35). Według badania Socransky'ego i wsp. (43) serotyp a A.actinomycetemcomitans wraz z Eikenella corrodens tworzy zielony kompleks bakteryjny, podczas gdy serotyp b pałeczek A.actinomycetemcomitans nie mógł być przyporządkowany do żadnego z kompleksów. Wykazano co prawda, że serotyp b, nawet z genotypem non-JP2, jest silnie leukotoksyczny jednakże podział JP2/non-JP2 jest mocno zakorzeniony i do chwili obecnej stosowany w mikrobiologii przyzębia (13). Według Hoglund-Aberg i wsp. (14) serotyp b jest praktycznie tożsamy z genotypem JP2. Pacjenci z reguły ulegają infekcji jednym z serotypów patogenu i nie zmienia się to $\mathrm{w}$ trakcie trwania choroby (39).

Niezależnie od serotypu pałeczek, podobnie jak w przypadku innych patogenów powodujących choroby przyzębia, wykazano duże różnice fenotypowe pomiędzy formą planktonową, obecną w jamie ustnej osób ze zdrowym przyzębiem, a formą biofilmową. Spośród 78 przebadanych protein, w przypadku 37 stwierdzono obniżenie, a w przypadku 13 zwiększenie ekspresji po wzroście w biofilmie. Większość tych ostatnich było białkami błony komórkowej oraz proteinami posiadającymi charakter immunogenny (26).

\section{MECHANIZMY KOLONIZACJI}

A.actinomycetemcomitans przejawia wiele form interakcji z komórkami gospodarza, począwszy od specyficznych mechanizmów kolonizacyjnych i obronnych, a skończywszy 
na szerokim spektrum toksyn. Udowodniono zdolność patogenu do łączenia się z ludzkimi komórkami nabłonkowymi (30). Za zdolność kolonizacji tej bakterii w dużym stopniu odpowiadają fimbrie. A.actinomycetemcomitans może występować w kilku postaciach, określanych na podstawie obrazu mikroskopowego jako przeźroczyste szorstkie, przeźroczyste gładkie i nieprzeźroczyste gładkie, z czego jedynie pierwsze wymienione są ufimbriowane (16). Przeciwciała skierowane przeciwko tym fimbriom blokowały adhezję bakterii do sztucznych powierzchni, komórek nabłonkowych policzka i do fibroblastów (9). Wykazano, że za łączenie bakterii z błoną śluzową policzków odpowiadają przede wszystkim adhezyny ApiA i Aae (4). Ta ostatnia jest homologiem Hap, analogicznej proteiny obecnej u H.influenzae i odpowiedzialnej za jej inwazyjność. Jest tak zwanym autotransporterem, czyli białkiem promującym własne przeniesienie z cytoplazmy bakterii na jej powierzchnię (38). Oprócz wymienionych, w adhezji A. actinomycetemcomitans uczestniczą inne proteiny, jak choćby Omp100, która wydaje się pełnić rolę w przyleganiu do keratynocytów (1). Bakterie pozbawione genów kodujących Aae i Omp100 były całkowicie niezdolne do łączenia się z komórkami nabłonkowymi policzka (47). Za zdolność do inwazji w głąb tkanek odpowiadają adhezyny nie powiązane $\mathrm{z}$ fimbriami. Jedną z nich jest glikoproteina, będąca receptorem dla fibronektyny, która po połączeniu z bakterią łączy się z integryną na powierzchni komórki gospodarza umożliwiając endocytozę. Według obserwacji mikroskopowej dochodzi do niej w około 30 minut. Niemal natychmiast po wniknięciu drobnoustrojów, komórki gospodarza zaczynają się dzielić oraz tworzyć, zawierające bakterie, wypustki cytoplazmatyczne (protruzje), łączące się z sąsiednimi komórkami (31). Zjawisko to, pierwotnie przypisywane unikalnie A.actinomycetemcomitans, okazuje się być powszechne dla mikrobioty jamy ustnej. Nie jest jasna rola tego zjawiska dla bakterii, które z jednej strony chronione są w ten sposób przed antybiotykami i mechanizmami obrony immunologicznej, z drugiej mogą indukować apoptozę lub stać się obiektem działania mechanizmów obrony wewnątrzkomórkowej (11). Co ciekawe, znacznie efektywniejsze we wnikaniu do komórek gospodarza okazały się być gładkie postacie pałeczek A.actinomycetemcomitans niż szorstkie (29). Niezależnie od tego, w wyniku połączenia z keratynocytami dochodzi do zmian fenotypowych w komórce docelowej, przejawiających się m.in. w modyfikacji ekspresji genów odpowiedzialnych za apoptozę (27). Kolejnym receptorem wiążącym jest obecny na komórkach gospodarza receptor dla czynnika aktywującego płytki krwi, który wiąże się z bakterią poprzez fosforylcholinę obecną na jej powierzchni. Komórkami gospodarza mogą być komórki śródbłonka naczyń i postuluje się, że to jest droga przenikania A.actinomycetemcomitans do krwiobiegu (40).

A.actinomycetemcomitans przejawia dodatkowo zdolność do łączenia się z kolagenem typu I, dominującym w przestrzeniach zewnątrzkomórkowych w tkankach przyzębia. Interesujący jest fakt, że wykazano szczególnie silne wiązanie pałeczek A.actinomycetemcomitans z kolagenem typu V, którego ilość w tkankach dziąsła w trakcie trwania reakcji zapalnej wzrasta 9-krotnie. Przy jednoczesnej ogólnej degradacji kolagenu w wyniku procesu chorobowego może to mieć znaczenie w inwazyjności A.actinomycetemcomitans. Powinowactwo bakterii do kolagenu dotyczy tylko ustrukturyzowanej formy, nie stwierdzono zjawiska nasilonego łączenia $\mathrm{z}$ kolagenem $\mathrm{w}$ formie rozpuszczalnej (32).

Podstawową, pierwotną formą biernej obrony jest tworzenie bakteryjnej matrycy zewnątrzkomórkowej z egzopolisacharydu. A.actinomycetemcomitans wytwarza poli-N- 
-acyetylo-glukozaminę (PGA), zbliżoną w budowie do PGA E.coli, S. aureus i S. epidermidis (21). W badaniu przeprowadzonym na szczurach dowiedziono, że szczepy A.actinomycetemcomitans pozbawione zdolności wytwarzania PGA wykazywały mniejszą przeżywalność niż pozostałe szczepy (41). PGA odgrywa również niebagatelną rolę w adhezji bakterii do komórek gospodarza (17). Za hipotezą o roli PGA w adhezji do tkanek twardych przemawia obserwacja, że A.actinomycetemcomitans wykazuje zdolność kolonizacji z błony śluzowej policzka na tkanki twarde, lecz nie w sekwencji odwrotnej (15). Niewykluczone, że syntezowanie PGA jest niezbędne do zainicjowania chorobotwórczości A.actinomycetemcomitans. W badaniu na szczurach wykazano, że szczep bakteryjny pozbawiony zdolności syntezy PGA nie inicjował resorpcji (8). Należy wyjaśnić, czy to jednostkowo zaobserwowany fenomen czy reguła, oraz czy nieinicjowanie resorpcji wynika po prostu z niezdolności do kolonizacji, czy też z jakiegoś procesu kaskadowego, w który PGA byłby zaangażowany.

\section{MECHANIZMY ZJADLIWOŚCI}

A.actinomycetemcomitans, podobnie jak wiele innych bakterii tworzących biofilm, konkuruje z innymi gatunkami wydzielając bakteriocyny. Są nimi aktynobacylina i aktynomycetemkomityna działające odpowiednio na Streptococcus sanguis i Peptostreptococcus anaerobius $(8,25)$. Poprzez selektywne hamowanie wzrostu tych konkretnych gatunków bakteryjnych stwarza się nisza ekologiczna w strukturze biofilmu i przestrzeni kieszonki do dalszego wzrostu patogenu.

Po kolonizacji, A.actinomycetemcomitans pobudza układ immunologiczny do reakcji. Pierwotnie dzieje się to na dwa sposoby. Po pierwsze, A.actinomycetemcomitans stymuluje komórki nabłonkowe dziąsła do produkcji IL-8 i ICAM-1, które są bardzo silnymi chemoatraktantami dla neutrofilów. Według badania autorów japońskich, serotyp $\mathrm{b}$ A.actinomycetemcomitans (a konkretnie jedna z linii komórkowych tego serotypu) szczególnie silnie wpływa na komórki dziąsłowe w warunkach in vitro, stymulując ekspresję IL-8 i ICAM-1. Pozostałe linie komórkowe oddziaływały w sposób śladowy (42). Po drugie, działanie chemoatrakcyjne wykazuje lipopolisacharyd bakterii, biorąc udział w zjawisku wzmożonego pobudzenia osteoklastów. Dynamika utraty kości w przebiegu zapalenia przyzębia powiązana jest, poprzez aktywację limfocytów $\mathrm{Th}_{17}, \mathrm{z}$ wewnątrzkomórkową ligandą aktywatora receptora nfkappaB (RANKL) mobilizującą osteoklasty (45). Wykazano, że lipopolisacharyd serotypu b A.actinomycetemcomitans szczególnie silnie aktywuje ekspresję genów różnicujących komórki $\mathrm{T}$ do subpopulacji $\mathrm{Th}_{17}$, co może prowadzić do nasilonej aktywności resorpcyjnej osteoklastów, a w konsekwencji do agresywniejszego przebiegu zapalenia przyzębia (3). Lipopolisacharyd ten szczególnie silnie aktywuje komórki Langerhansa, prowadząc $\mathrm{z}$ kolei do różnicowania i aktywacji $\mathrm{Th}_{17}$ oraz sekrecji powiązanych z tą linią komórkową cytokin prozapalnych, jak IL-6, IL-17 i IL-21, a także produkcji RANKL i nadmiernej aktywacji osteoklastów (28).

Podstawowymi dwiema cytotoksynami produkowanymi i wydzielanymi przez paleczki A. actinomycetemcomitans są genotoksyna CDT (CDT) i leukotoksyna A (LtxA). Genotoksyna CDT, wydzielana przez niektóre bakterie Gram-ujemne, powoduje śmierć komórek gospodarza poprzez zahamowanie ich proliferacji w fazie $\mathrm{G}_{2}$ cyklu komórkowego i zwiększenie ekspresji RANKL, co, jak już wspomniano wcześniej, stymuluje osteo- 
klasty i prowadzi do apoptozy komórki (15). Genotoksyna przenika przez błonę komórki łącząc się prawdopodobnie z cholesterolem, następnie poprzez aparat Golgiego i retikulum endoplazamatyczne dociera do jądra komórkowego (7). Genotoksyna CDT ze względu na zdolność blokowania cyklu komórkowego znajduje się pod szczególną uwagą lekarzy onkologów. Wykazano jej związek z dysplazją komórek wątroby u myszy i sugeruje się związek pomiędzy występowaniem dysplazji w jamie ustnej a infekcją szczepami bakteryjnymi zdolnymi do produkcji CDT (6). LtxA powoduje z kolei tworzenie porów w błonie leukocytów i lizę tych komórek (15). Dodatkowo, bierze udział w degranulacji neutrofilów i odpowiedzi prozapalnej makrofagów, co dodatkowo nasila komponentę nieswoistą odpowiedzi immunologicznej (19). LtxA należy do grupy toksyn bakteryjnych RTX, do których zaliczana jest również hemolizyna E.coli. Wyjątkowość LtxA polega na zdolności do modyfikowania cech bakterii. Leukotoksyna gromadzona jest w specjalnych pęcherzykach i na powierzchni błony komórkowej (22). Wykazano, że zjawisko to zachodzi u szorstkiej postaci pałeczek A.actinomycetemcomitans. Z kolei postaci gładkie (w tym genotyp JP2) produkują i wydzielają duże ilości tej toksyny, bez jej wiązania na powierzchni błony komórkowej. Co interesujące, mutacje genu tad współodpowiedzialnego za tworzenie fimbrii, które powodowały utratę zdolności adhezji, skutkowały także uwalnianiem LtxA (20). Docelowym receptorem dla LtxA jest heterodimer LFA-1 (CD11/ CD18) na powierzchni neutrofilów (24). Połączenie z receptorem LFA-1 indukuje sekrecję zewnątrzkomórkowego ATP, który - obok klasycznego antygenu - jest współodpowiedzialny za aktywację kompleksu inflamasomu i aktywowanie oraz wydzielanie interleukiny-1 oraz interelukiny-18 (33). W związku z tym wydaje się, że główne działanie LtxA nie tyle jest powiązane ze śmiercią komórek immunokompetentnych, w szczególności makrofagów, ale z towarzyszącym jej wyrzutem cytokin prozapalnych i wzmożoną aktywnością osteoklastyczną. Istnieje hipoteza, według której makrofagi poddane działaniu LtxA ulegają specyficznemu rodzajowi śmierci komórkowej nazywanemu pyroptozą. Komórki ulegające pyroptozie zwiększają swoją objętość, ponieważ w wyniku powstania porów transbłonowych dochodzi do zmian ciśnienia osmotycznego, wsączania wody do komórki, obrzęku komórki i wydzielania IL-1 i IL-18 (5). W wyniku pyroptozy dochodzi także do aktywacji kaspazy-1, składowej kompleksu inflamasomu (23). Wpływ LtxA na występowanie agresywnego zapalenia przyzębia jest udokumentowany, według Haubeka i wsp. (10) osoby z kieszonkami zainfekowanymi genotypem JP2 miały 18-krotnie większe ryzyko wystąpienia agresywnego zapalenia przyzębia niż osoby zainfekowane genotypem non-JP2. LtxA wzmaga wydzielanie i tworzenie zewnątrzkomórkowej sieci DNA tworzonej przez neutrofile ( $z$ ang. neutrophil extracellular trap, NET). NET oprócz niszczenia bakterii obecności powiązanych z DNA protein i peptydów przeciwbakteryjnych, dodatkowo wzmaga komponentę nieswoistą odpowiedzi zapalnej, a w konsekwencji nasila destrukcję zapalną tkanek przyzębia. Jest to możliwe, ponieważ liza neutrofilów wynikająca z działania leukotoksyny jest zjawiskiem stosunkowo powolnym, co umożliwia komórce docelowej na wcześniejsze wytworzenie NET. Z tego powodu w przestrzeni międzykomórkowej, oprócz uporządkowanego DNA obecnego w NET, stwierdza się także chaotycznie występujące strzępki DNA wynikłego z lizy komórek. Ten fragmentowany DNA jest silnym czynnikiem chemoatrakcyjnym, co powoduje migrację kolejnych neutrofilów i - w obecności bakterii A.a. produkującego leukotoksynę - może prowadzić do błędnego koła nasilonej destrukcji tkanki łącznej i kości (12). 


\section{PODSUMOWANIE}

Coraz więcej dowodów wydaje się wskazywać na to, że A.actinomycetemcomitans ma wpływ na zapoczątkowanie zapalenia przyzębia, natomiast w późniejszych stadiach choroby biofilm ulega silnej dywersyfikacji gatunkowej (2). A.actinomycetemcomitans dzięki licznym swoistym mechanizmom kolonizacji zasiedla efektywnie szczelinę dziąsłową, natomiast po zainicjowaniu destrukcji tkanek i powstaniu kieszonki przyzębnej stwarza warunki dla bakterii konkurujących. Takim patogenem jest P.gingivalis. Udowodniono, że posiada on zdolność obniżenia aktywności LtxA (18), a dzięki wydzielaniu gingipainy posiada zdolność hamowania kolonizacji i namnażania A.actinomycetemcomitans (46). Wydaje się jednak, że rola A.actinomycetemcomitans w zapoczątkowaniu nasilonego procesu chorobowego jest tak znacząca, że zasadne jest skupienie uwagi na tej bakterii w kontekście profilaktyki i leczenia zapalenia przyzębia pojawiającego się u młodzieży, obejmującego wcześnie wyrznięte uzębienie stałe.

\section{PIŚMIENNICTWO}

1. Asakawa R, Komatsuzawa H, Kawai T, Yamada S i inni. Outer membrane protein 100, a versatile virulence factor of Actinobacillus actinomycetemcomitans. Mol Microbiol 2003; 50: 1125 - 39 .

2. Dahlen $G$, Claesson R, Aberg CH, Haubek D i inni. Subgingival bacteria in Ghanaian adolescents with or without progression of attachment loss. J Oral Microbiol 2014; 6; PMID:24834145; http://dx.doi.org/10.3402/jom.v6.23977.

3. Diaz-Zuniga J, Yanez JP, Alvarez C, Melgar-Rodriguez S i inni. Serotype-dependent response of human dendritic cells stimulated with Aggregatibacter actinomycetemcomitans. J Clin Periodontol 2014; 41: $242-51$.

4. Fine DH, Markowitz K, Furgang D, Velliyagounder K. Aggregatibacter actinomycetemcomitans as an early colonizer of oral tissues: epithelium as a reservoir? J Clin Microbiol 2010; 48: 4464 - 73.

5. Fink SL, Cookson BT. Apoptosis, pyroptosis, and necrosis: mechanistic description of dead and dying eukaryotic cells. Infection and immunity 2005; 73: $1907-16$.

6. Ge Z, Rogers AB, Feng Y, Lee A i inni. Bacterial cytolethal distending toxin promotes the development of dysplasia in a model of microbially induced hepatocarcinogenesis. Cell Microbiol 2007; 9: 2070 - 80.

7. Guerra L, Teter K, Lilley BN, Stenerlow B i inni. Cellular internalization of cytolethal distending toxin: a new end to a known pathway. Cell Microbiol 2005; 7: $921-34$.

8. Hammond BF, Lillard SE, Stevens RH. A bacteriocin of Actinobacillus actinomycetemcomitans. Infect Immun 1987; 55: 686 - 91.

9. Harano K, Yamanaka A, Okuda K. An antiserum to a synthetic fimbrial peptide of Actinobacillus actinomycetemcomitans blocked adhesion of the microorganism. FEMS Microbiol Lett 1995; 130: 279 - 85.

10. Haubek D, Ennibi OK, Poulsen K, Vaeth $M$ i inni. Risk of aggressive periodontitis in adolescent carriers of the JP2 clone of Aggregatibacter (Actinobacillus) actinomycetemcomitans in Morocco: a prospective longitudinal cohort study. Lancet 2008; 371: $237-42$. 
11. Henderson B, Ward JM, Ready D. Aggregatibacter (Actinobacillus) actinomycetemcomitans: a triple A* periopathogen? Periodontology 2000 2010; 54: 78 - 105.

12. Hirschfeld J, Roberts HM, Chapple IL, Parcina M i inni. Effects of Aggregatibacter actinomycetemcomitans leukotoxin on neutrophil migration and extracellular trap formation. J Oral Microbiol 2016; 8: 33070.

13. Hoglund Aberg C, Haubek D, Kwamin F, Johansson A i inni. Leukotoxic activity of Aggregatibacter actinomycetemcomitans and periodontal attachment loss. PLoS One 2014; 9: e104095.

14. Hoglund Aberg C, Kwamin F, Claesson R, Dahlen $G$ i inni. Progression of attachment loss is strongly associated with presence of the JP2 genotype of Aggregatibacter actinomycetemcomitans: a prospective cohort study of a young adolescent population. $\mathrm{J}$ Clin Periodontol 2014; 41: 232 - 41.

15. Hoglund Aberg C, Kelk P, Johansson A. Aggregatibacter actinomycetemcomitans : Virulence of its leukotoxin and association with aggressive periodontitis. Virulence 2015; 6: $188-95$.

16. Inouye T, Ohta H, Kokeguchi S, Fukui K i inni. Colonial variation and fimbriation of Actinobacillus actinomycetemcomitans. FEMS Microbiol Lett 1990; 57: 13 - 7.

17. Izano EA, Amarante MA, Kher WB, Kaplan JB. Differential roles of poly-N-acetylglucosamine surface polysaccharide and extracellular DNA in Staphylococcus aureus and Staphylococcus epidermidis biofilms. Appl Environ Microbiol 2008; 74: 470 - 6.

18. Johansson A, Hanstrom L, Kalfas S. Inhibition of Actinobacillus actinomycetemcomitans leukotoxicity by bacteria from the subgingival flora. Oral Microbiol Immunol 2000; 15: $218-25$.

19. Johansson A. Aggregatibacter actinomycetemcomitans leukotoxin: a powerful tool with capacity to cause imbalance in the host inflammatory response. Toxins 2011; 3: $242-59$.

20. Kachlany SC, Fine DH, Figurski DH. Secretion of RTX leukotoxin by Actinobacillus actinomycetemcomitans. Infect Immun 2000; 68: $6094-100$.

21. Kaplan JB, Velliyagounder $K$, Ragunath $C$, Rohde $H$ i inni. Genes involved in the synthesis and degradation of matrix polysaccharide in Actinobacillus actinomycetemcomitans and Actinobacillus pleuropneumoniae biofilms. J Bacteriol 2004; 186: 8213 - 20.

22. Kato S, Kowashi Y, Demuth DR. Outer membrane-like vesicles secreted by Actinobacillus actinomycetemcomitans are enriched in leukotoxin. Microb Pathog 2002; 32: $1-13$.

23. Kroemer G, Galluzzi L, Vandenabeele P, Abrams $J$ i inni. Classification of cell death: recommendations of the Nomenclature Committee on Cell Death 2009. Cell Death Differ 2009; 16: 3 - 11 .

24. Lally ET, Kieba IR, Sato A, Green CL i inni. RTX toxins recognize a beta2 integrin on the surface of human target cells. J Biol Chem 1997; 272: 30463 - 9.

25. Lima FL, de Carvalho MA, Apolonio AC, Bemquerer MP i inni. Actinomycetemcomitin: a new bacteriocin produced by Aggregatibacter (Actinobacillus) actinomycetemcomitans. J Ind Microbiol Biotechnol 2008; 35: 103 - 10.

26. Llama-Palacios A, Potupa O, Sanchez MC, Figuero E i inni. Aggregatibacter actinomycetemcomitans growth in biofilm versus planktonic state: differential expression of proteins. J Proteome Res 2017; 16: 3158 - 67. 
27. Mans JJ, Baker HV, Oda D, Lamont RJ i inni. Distinctive characteristics of transcriptional profiles from two epithelial cell lines upon interaction with Actinobacillus actinomycetemcomitans. Oral Microbiol Immunol 2006; 21: 261 - 7.

28. Melgar-Rodrilguez S, Diaz-Zuniga J, Alvarez C, Rojas L i inni. Serotype b of Aggregatibacter actinomycetemcomitans increases osteoclast and memory T-lymphocyte activation. Molecular Oral Microbiol 2016; 31: 162 - 74.

29. Meyer DH, Sreenivasan PK, Fives-Taylor PM. Evidence for invasion of a human oral cell line by Actinobacillus actinomycetemcomitans. Infect Immun 1991; 59: 2719 - 26.

30. Meyer DH, Fives-Taylor PM. Characteristics of adherence of Actinobacillus actinomycetemcomitans to epithelial cells. Infect. Immun 1994; 623: 928 - 35.

31. Meyer DH, Lippmann JE, Fives-Taylor PM. Invasion of epithelial cells by Actinobacillus actinomycetemcomitans: a dynamic, multistep process. Infect Immun 1996; 64: $2988-97$.

32. Mintz KP, Fives-Taylor PM. Binding of the periodontal pathogen Actinobacillus actinomycetemcomitans to extracellular matrix proteins. Oral Microbiol Immunol 1999; 14: $109-16$.

33. Nędzi-Góra M, Kowalski J, Górska R. The Immune Response in Periodontal Tissues. Arch Immunol Ther Exp 2017; 65: 421 - 9.

34. Norskov-Lauritsen N, Kilian M. Reclassification of Actinobacillus actinomycetemcomitans, Haemophilus aphrophilus, Haemophilus paraphrophilus and Haemophilus segnis as Aggregatibacter actinomycetemcomitans gen. nov., comb. nov., Aggregatibacter aphrophilus comb. nov. and Aggregatibacter segnis comb. nov., and emended description of Aggregatibacter aphrophilus to include $\mathrm{V}$ factor-dependent and $\mathrm{V}$ factor-independent isolates. Int J Syst Evol Microbiol 2006; 56: 2135 - 46.

35. Perry MB, Maclean LM, Brisson JR, Wilson ME. Structures of the Antigenic O-Polysaccharides of Lipopolysaccharides Produced by Actinobacillus actinomycetemcomitans Serotypes a, c, d and e. FEBS J 1996; 242: 682 - 8 .

36. Potts TV, Zambon JJ, Genco RJ. Reassignment of Actinobacillus actinomycetemcomitans to the genus Haemophilus as Haemophilus actinomycetemcomitans. Int J Syst Bacteriol 1985; 35: $337-41$.

37. Rahamat-Langendoen JC, van Vonderen MG, Engstrom LJ, Manson WL i inni. Brain abscess associated with Aggregatibacter actinomycetemcomitans: case report and review of literature. J Clin Periodontol 2011; 38: 702 - 6 .

38. Rose JE, Meyer DH, Fives-Taylor PM. Aae, an autotransporter involved in adhesion of Actinobacillus actinomycetemcomitans to epithelial cells. Infect Immun 2003; 71: $2384-93$.

39. Saarela $M$, Asikainen $S$, Alaluusua $S$, Pyhala L i inni. Frequency and stability of monoor poly-infection by Actinobacillus actinomycetemcomitans serotypes a, b, c, d or e. Oral Microbiol Immunol 1992; 7: 277 - 9.

40. Schenkein HA, Barbour SE, Berry CR, Kipps B i inni. Invasion of human vascular endothelial cells by Actinobacillus actinomycetemcomitans via the receptor for plateletactivating factor. Infect Immun 2000; 68: 5416 - 9.

41. Shanmugam M, Gopal P, El Abbar F, Schreiner HC i inni. Role of exopolysaccharide in aggregatibacter actinomycetemcomitans-induced bone resorption in a rat model for periodontal disease. PLoS ONE 2015; 10: e0117487. 
42. Shimada T, Sugano N, Nishihara R, Suzuki K i inni. Differential effects of five Aggregatibacter actinomycetemcomitans strains on gingival epithelial cells. Oral Microbiol Immunol 2008; 23: 455 - 8.

43. Socransky SS, Haffajee AD, Cugini MA, Smith C i inni. Microbial complexes in subgingival plaque. .J Clin Periodontol 1998; 25: $134-44$.

44. Spitznagel J Jr, Kraig E, Kolodrubetz D. Regulation of leukotoxin in leukotoxic and nonleukotoxic strains of Actinobacillus actinomycetemcomitans. Infect Immun 1991; 59: $1394-401$.

45. Takahashi K, Azuma T, Motohira H, Kinane DF i inni. The potential role of interleukin-17 in the immunopathology of periodontal disease. J Clin Periodontol 2005; 32: $369-74$.

46. Takasaki K, Fujise O, Miura M, Hamachi $T$ i inni. Porphyromonas gingivalis displays a competitive advantage over Aggregatibacter actinomycetemcomitans in co-cultured biofilm. J Periodontal Res 2013; 48: 286 - 92.

47. Yue G, Kaplan JB, Furgang D, Mansfield KG i inni. A second Aggregatibacter actinomycetemcomitans autotransporter adhesin exhibits specificity for buccal epithelial cells in humans and Old World primates. Infect Immun 2007; 75: $4440-8$.

48. Zambon JJ, Christersson LA, Slots JJ. Actinobacillus actinomycetemcomitans in human periodontal disease. Prevalence in patient groups and distribution of biotypes and serotypes within families. J Periodontol 1983; 54: 707 - 11.

Otrzymano: 3 VII $2018 \mathrm{r}$.

Adres Autora: 00-246 Warszawa ul. Miodowa 18, Zakład Chorób Błony Śluzowej i Przyzębia WUM 